\title{
Reflection on the College English Teaching Reform from the Perspective of Combination of Courses with Ideological and Political Education
}

\author{
*Bing $\mathrm{He}$ \\ School of foreign language, Dalian Jiaotong University, DaLian, China \\ *Corresponding author e-mail: rachelhe2008@163.com
}

\begin{abstract}
College English is a basic language course with a long history. The importance and necessity of ideological and political education in College English class should be excavated. In teaching, we should not only pay attention to imparting knowledge, but also take Xi Jinping's new era socialism with Chinese characteristics as the guiding ideology, and take the socialist core values and Chinese cultural values as the main content, and enhance the ideological and problem consciousness of College English teaching. Through the integration of English class and politics, with the effective guidance from English teachers, students will correctly understand the differences between China and the west, taking the essence to discard their dross, guiding students to establish cultural self-confidence. In this way, students will become socialist builders and successors with Chinese feelings, international vision and cross-cultural communication ability.
\end{abstract}

Keywords: higher education, curriculum ideological and political education, English teaching

\section{INTRODUCTION}

The so-called curriculum ideological and political education is to integrate ideological and political education, such as ideological concept, political point of view, moral norms into the teaching of professional courses (non-ideological and political courses). According to the characteristics of the course, we can integrate these things, including socialism with Chinese characteristics and Chinese dream publicity, ideal and belief education, Chinese excellent traditional culture education, Chinese excellent traditional virtue, professional culture, craftsman spirit, revolutionary traditional education, national defence education, labor education, etc. into the professional course teaching, and guide students to establish correct world outlook, outlook on life and values, and strengthen socialism, the communist faith, firmly support the leadership of the Communist Party of China, unswervingly follow the road of socialism with Chinese characteristics, firmly believe in the road of socialism with Chinese characteristics, the theory, the system and the culture, enhance the mission, resolutely listen to the party's words and follow the party, and strive to be a qualified socialist builder and reliable successor.

"Ideological and political education in curriculum" is a new teaching theory and a new teaching style containing the goal of Ideological and political education. [1] Among them, curriculum is the carrier of Ideological and political education, and ideological and political education is the soul of curriculum. It is also a cultural product under the background of diversified society. It aims to influence the students' world outlook, outlook on life and values through the teaching process of Marxist theory and socialist core values. In addition, the ideological and political education resources of the subject can be further explored to promote the continuous improvement of the course so as to realize the Course Association Advance together.

\section{THE KIND OF TALENTS UNIVERSITIES SHOULD CULTIVATE}

As the main source of personnel training, only by firmly implementing the party's educational policy, adhering to the direction of running a socialist university, following the basic requirements of education serving the people, governing the country and administration of the Communist Party of China, consolidating and developing the socialist system with Chinese characteristics, reform and opening-up, and socialist modernization can colleges and universities take on the responsibility of training the new generation. [2]

Colleges and universities should make great efforts to construct the educational pattern of Ideological and political courses. The key to this pattern of education is to make clear the basic training direction of cultivating people with morality. The core is to promote the coordinated development of Ideological and political courses and English courses. On the basis of continuing to consolidate the role of the main channel of Ideological and political courses, we should promote the wide coverage of 
the courses and further improve various professional studies.

\section{CURRENT SITUATION}

As a basic course, College English has a wide coverage, great influence, high learning requirements and unique language environment. Therefore, it is very important to find out the differences between English teaching and other courses in the process of Ideological and political implementation, and to build a path of Ideological and political implementation combining its own characteristics. English teaching should combine imparting knowledge, cultivating ability and ideological and political education, so as to cultivate the correct values of college students.

Each module is designed with "worldwide" module, which provides students with relevant reading materials related to foreign culture and widens students' knowledge, but there are few materials related to Chinese traditional culture. The so-called "Chinese Cultural Aphasia" hinders the wide spread of Chinese culture in the world to a large extent. [3] Contemporary college students' understanding of "curriculum ideological and political" has not been popularized, and the promotion of "curriculum ideological and political" in English discipline has not been implemented in Colleges and universities. However, we can also see that the proportion of students who think it is necessary to promote traditional Chinese culture is relatively high.

Students learn ideological and political education mainly through the content of English teaching materials told by teachers in class. In order to understand the elements of Ideological and political education contained in the knowledge, students should contact with ideological and political values and moral standards, and transform it into their own quality and good moral training, while learning the knowledge in the textbook.

In English teaching materials, some of them can be well integrated into the functions and elements of Ideological and political education. On the contrary, some textbooks only focus on the application of gorgeous language, especially reflecting the knowledge of Western literature. Some are lack of inheritance and accumulation of Chinese traditional culture and lack of understanding and attention to the facts of civil affairs. This kind of learning will make students lose confidence in cultural development.

\section{THE NECESSITY OF INTEGRATING IDEOLOGICAL AND POLITICAL EDUCATION INTO COLLEGE ENGLISH TEACHING}

The opinion on "Further strengthening and improving the ideological and political education of college students" points out that "all courses in colleges and universities have the function of educating people, and all teachers have the responsibility of educating people. [4] We should deepen the ideological and political education resources of the English courses. "[5] Colleges and universities pay more attention to the cultivation of students' professional skills, and pay less attention to the humanistic moral quality. Language is the carrier of culture and thinking. English is not only a tool of communication, but also has its human nature, which means that college English curriculum bears the responsibility of improving students' comprehensive quality. In the process of learning English, college students not only learn language knowledge, but also learn the rich cultural and historical background. The humanistic nature of College English can cultivate students' patriotic feelings and enhance their sense of identity with their motherland. Teachers can also guide students to establish a correct world outlook, outlook on life, values, and develop good character by comparing the differences between China and the West. College English, which has the characteristics of knowledge and humanity, plays an important role in Ideological and political education.

\section{REFLECTION ON THE INTEGRATION OF IDEOLOGICAL AND POLITICAL EDUCATION IN COLLEGE ENGLISH}

\subsection{Construct a good atmosphere}

Environment has different influences on English learning. Creating an environment that can exercise the ability of English expression is very helpful to English learning. The same is true of Ideological and political education, which needs constant integration of unique cultural environment. In campus learning, college students should also contact the society from time to time, increase their extracurricular activities to see the outside world and broaden their life experience. Campus environment is important, but students need understand and pay attention to the surrounding environment and social environment of the school. There are many factors that determine personal growth, among which internal and external environment are indispensable.

Chairman Xi Jinping pointed out: "Qualified teachers should be moral qualified persons first. And good teachers should first be models of virtue and moral integrity. Teachers are the mirror of students' moral cultivation. Teachers' moral consciousness and ability are directly related to the quality and effect of Ideological and political education. Moral education consciousness refers to the consciousness that teachers should pay attention to moral education resources, grasp the opportunity of moral education, and cultivate students' moral quality. Teachers are the implementers of curriculum and the main body of teaching practice. [6] Whether the professional teachers can accept and practice the new idea of curriculum ideological and political education and adapt to the new requirements of curriculum ideological and political education is the key to construct a new pattern of school 
moral education. A professional teacher should not only be an "expert" who knows a lot of things, but also be a good teacher with ideals and beliefs, moral sentiments, solid knowledge and benevolence. The ability of moral education means that teachers should have excellent skills in the process of cultivating students' moral quality. Teachers' work is not only to spread knowledge, ideas and truth, but also to shape soul, character and personality. Teachers should take "for the lifelong development of every student" as the core idea, focus on the ideological concerns of young people, focus on the cultivation of students' moral literacy, strengthen positive guidance, indepth understanding of doubts, and strive to combine ideological, theoretical, intellectual and acceptable teaching methods, so as to continuously enhance the affinity of Ideological and political education harmony and appeal. [7]

\subsection{College teacher's new challenge}

College English teachers should be college English teachers in the new era. They should actively pay attention to the development trend, advanced ideas and efficient methods of Ideological and political education. They should first enhance the awareness of curriculum education, carry forward China's excellent traditional culture, be "guiders" for students to practice socialist core values, and put ideological and political education throughout the teaching process. For example, when preparing for a class, College English teachers should not only pay attention to English knowledge, but also conduct in-depth ideological excavation from the materials, find out the fit point between English education and socialist core values, and strive to achieve a win-win situation between the two; in the course, when learning the contents of listening, reading, translation and other parts, guide students to understand the social values, ethics and so on of China and the West In terms of differences, in combination with China's national conditions, we should cultivate college students' correct cross-cultural awareness, improve their cognitive ability of political position, and implant Chinese excellent traditional culture, values and national awareness into their hearts; after class, teachers can give students more humanistic care and psychological guidance by establishing QQ group and wechat group, such as pushing articles with ideological and political significance.

It is necessary to establish a team and a professional course group on this basis. The group is responsible for the research and planning of the ideological and political of English courses. [8] They should develop the standards of the course and the organizational form of Ideological and political classroom teaching, construct the ideological and political material resource database of courses, and formulate the ideological and political semester plan. Besides, the team should produce Ideological and political courseware, define the key and difficult points of Ideological and political courses, and design the teaching methods of Ideological and political courses. When the professional course group prepares lessons collectively, it should not only prepare courses, but also prepare ideological and political education. At the end of the semester, teachers should be organized to share and exchange their experience in Ideological and political teaching.

\subsection{New content in English teaching}

In addition to the teaching of language knowledge, the course content should be rich, integrated into the core ideology of Ideological and political courses, and reflect its cultural nature. "Cultural learning as an explicit course runs through foreign language education all the time, but not as an invisible course covered by the training goal of language skills."

We should increase the content of Chinese history, culture, politics, economy, etc. Only in this way, can we enhance cultural self-confidence, increase the content of cultural comparison between Chinese and Western civilizations, cultivate the awareness of cross-cultural communication, enhance cultural adaptability and understanding, and improve the ability of cross-cultural communication;

\section{CONCLUSION}

College students are the hope of national development and the reserve force of national construction in the future. To do a good job in Ideological and political work of college students is the duty of every student, and also can improve their comprehensive quality. Strengthening the ideological and political education of college students is an important task of building a socialist country, which has a profound impact on the development of society. [9] Therefore, the ideological and political education into the College English classroom, using its many advantages in the course, combined with teaching materials, through the practice of theoretical basis, improve the quality of Ideological and political education of college students, get rid of its current predicament. College English ideological and political education is related to the overall quality of college students and the realization of the "Chinese dream". College English teachers take effective ways to inspire students to think, and let the seeds of Ideological and political education be imperceptibly planted in students' hearts in College English teaching, so as to truly realize the substantial transformation from "Ideological and political education" to "curriculum ideological and political education". In the process of Ideological and political course practice, there are often some unnecessary problems. Therefore, we should improve teaching methods, carry out diversified teaching, improve classroom teaching efficiency, improve the harmonious relationship between teachers and students, and improve the comprehensive theoretical literacy of teachers and students. 


\section{REFERENCES}

[1] Liu Xiaoyang. Research on the implementation path of College English "Ideological and Political Courses" [J]. Journal of Jilin University of business and technology 2018 (10)

[2] Xi Jinping. The ideological and political work runs through the whole process of education and Teaching [EB /OL]. (.Http:/, /news.xinhuanet.com/politics)

[3] Li Jie. On the integration of College Students' Ideological and political education and English Classroom Teaching [J]. Science and technology information, 2017, 15 (02): 143-144

[4] Zhang Yiling. The combination of College English teaching and ideological and political education of College Students

Practice [J]. Journal of Jiangxi Electric Power Vocational and technical college, 2018, 31 (01): 48-49

[5] Zhu Shuqin, Chen Zhen. The application of innovative strategies in Ideological and Political Education [J]. Education Modernization, 2017, 4 (27): $179-180$

[7] $\mathrm{Xi}$ Jinping. Ideological and political work runs through education and teaching. Process [EB / OL] (2016-12-08) [2019-01-11].

[8] Liu Xiaoyang. The implementation path of College English curriculum ideological and Political Education Research [J]. Journal of Jilin Institute of business, 2018 (10)

[9] Bian Yunfei, di Tianxiu. From "curriculum ideological and political" Problems in College English teaching and their solutions Methods [J]. Curriculum education research, 2019 (14): 119 